\title{
Hospital Wastewater-Important Source of Multidrug Resistant Coliform Bacteria with ESBL-Production
}

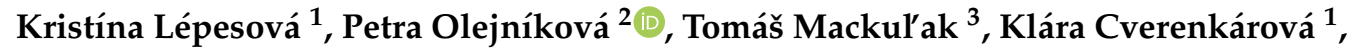 \\ Monika Krahulcová ${ }^{1}$ (D) and Lucia Bírošová ${ }^{1, *(D)}$ \\ 1 Faculty of Chemical and Food Technology, Department of Nutrition and Food Quality Assessment, \\ Slovak University of Technology, Radlinského 9, 81237 Bratislava, Slovakia; nagyovak5@gmail.com (K.L.); \\ klara.cverenkarova@stuba.sk (K.C.); monika.krahulcova@stuba.sk (M.K.) \\ 2 Faculty of Chemical and Food Technology, Institute of Biochemistry and Microbiology, Slovak University of \\ Technology, Radlinského 9, 81237 Bratislava, Slovakia; petra.olejnikova@stuba.sk \\ 3 Department of Environmental Engineering, Faculty of Chemical and Food Technology, Slovak University of \\ Technology, Radlinského 9, 81237 Bratislava, Slovakia; tomas.mackulak@stuba.sk \\ * Correspondence: lucyja.birosova@gmail.com; Tel.: +421-2-5932-5478
}

Received: 11 September 2020; Accepted: 22 October 2020; Published: 26 October 2020

\begin{abstract}
This work compares the prevalence of antibiotic resistant coliform bacteria in hospital wastewater effluents in Slovak (SR) and Czech Republic (ČR). It also describes selected antibiotic resistant isolates in view of resistance mechanism and virulence factor. The highest number of multidrug resistant bacteria was detected in samples from the hospital in Valašské Meziříčí (ČR). More than half of resistant isolates showed multidrug resistance phenotype as well as strong ability to form biofilm. In $42 \%$ of isolates efflux pump overproduction was detected together with tet $A$ and tet $E$ genes. The production of extended-spectrum $\beta$-lactamases in coliform isolates was encoded mainly by $b l a_{T E M}, b l a_{C T X-M-2}$ and $b l a_{C T X-M-8 / 25}$ genes. About $62 \%$ of resistants contained a combination of two or more extended spectrum beta-lactamases (ESBL) genes. Our results strengthen the fact that hospital effluents are a source of multidrug resistant bacteria which can spread their resistance genes to other bacteria in wastewater treatment plants (WWTPs). Accordingly, hospital wastewater should be better treated before it enters urban sewerage.
\end{abstract}

Keywords: antibiotic resistance; hospital wastewaters; ESBL; biofilm; efflux pumps

\section{Introduction}

Recently, the World Health Organization announced that antibiotic resistance is emerging, and we are fast running out of treatment options [1]. In Europe, 20-30\% of hospitalized patients receive antibiotics (ATB) treatment during their hospitalization. This creates good conditions for the development of ATB resistance due to high selective pressure. In addition, pathogenic bacteria can also spread in the hospital through the health care personnel. Antibiotic resistant bacteria (ARB) may escape from these facilities in infected patients and the sewer system. This situation may be worsened when effluents from healthcare facilities are directly discharged with no prior treatment in the wastewater network. Sewerage systems collect wastewater not only from households but also from hospitals, psychiatric clinics, retirement homes and other health care facilities that are a major source of pharmaceuticals [2]. Hospital effluents (HEs) are ranked as a special category because of their highly hazardous and toxic character. These types of wastewater contain cocktail of ATB, disinfectants, metabolized drugs, and sensitive and resistant bacteria from hospitalized patients [3]. ATBs in subinhibitory concentrations presented in wastewater act as signal molecules and regulatory substances inducing horizontal gene transfer, mutagenesis, and SOS bacterial response as well as the 
selection of resistant bacterial strains [4]. This makes HEs significant and important contributors to the spread and development of ATB resistance in wastewater and the environment. Some studies have reported lower levels of ARB and ATB resistance genes (ARGs) in municipal wastewater compared to HEs [5-7]. This means that wastewater released from healthcare facilities can increase the number of coliforms inflowing to the municipal WWTPs. According to this fact, HEs should be better treated before entering sewerage. This treatment could involve the use of boron doped diamond electrodes, ferrates or ozonation $[8,9]$.

In 2017 the World Health Organization published a list of ATB-resistant "priority pathogens". The most critical group of all includes multidrug resistant (MDR) bacteria that pose a particular threat in hospitals, nursing homes, and among patients whose care requires devices such as ventilators and blood catheters. These include Acinetobacter spp., Pseudomonas spp. and various Enterobacteriaceae (including Klebsiella spp., E. coli, Serratia spp., and Proteus spp.) producing extended spectrum beta-lactamases (ESBL) or carbapenemases [10]. ESBL-producing bacteria cause resistance to $\beta$-lactam ATBs containing an oxyimino group (e.g., ceftazidime, cefotaxime, aztreonam) together with resistance to other classes of non-penicillin ATBs, including fluoroquinolones (FQ), aminoglycosides, trimethoprim/sulfa-methoxazole and $\mathrm{B}$-lactam/B-lactamase inhibitor combinations. These bacteria are responsible for host prolonged hospital stay, increased treatment costs, morbidity, and mortality [11]. Recent studies have shown the high frequency of human intestinal carriage of ESBL-producing E. coli in both hospital and community settings [5]. In Paris a 10-fold increase in the rate of healthy subjects with ESBL-producing E. coli fecal carriage over a five-year period (2006-2011) was found [11]. Between 2002 and 2013 the incidence of ESBL-producing Enterobacteriaceae increased up to four-fold in French hospitals. During this decade, the proportion of E. coli producing ESBL increased among all strains of Enterobacteriaceae family from $19-59 \%$ [5].

Biofilm formation is one of the most important virulence factors of pathogenic bacteria, which enable bacteria to escape the host defense mechanism. Moreover, it was shown that bacteria in biofilm are 1000 times more resistant due to slow drugs penetration and altered microenvironment [12]. Additionally, a biofilm matrix can improve intracellular communication as well as horizontal gene transfer due to physical proximity and cell density, while the conjugation can be up to 700 times more effective compared to wild-type bacterial cells [13]. Sabir et al. (2017) highlighted the increased incidence of urinary tract infections caused by E. coli, E. cloacae or K. pneumoniae showing a strong intensity of biofilm production which can subsequently be released into wastewater [12].

This study compares the occurrence of ATB-resistant coliform bacteria in effluents from hospitals and healthcare facilities. The second part of the work is focused on the identification and characterization of selected ATB-resistant coliform bacteria isolated from HEs.

\section{Materials and Methods}

\subsection{Characterization of Healthcare Facilities and Description of Sampling Methodology}

Samples of wastewater were collected at the outlet point of canalization in healthcare facilities situated in the Slovak and Czech Republics, as $2 \mathrm{~h}$-decanted samples in sterile falcon tubes between 2014 and 2017. Two different samples were collected from each facility. The HE samples were immediately transferred into the laboratory for microbiology analysis. The data regarding the number of beds, equipment type and recipient of wastewater are listed in Table 1. Most listed hospitals treat wastewater only by nitrification. Wastewater from the National Cancer Institute of St. Elizabeth (NCISE), the University Hospital in Ružinov, the Hospital in Malacky, the Children's Faculty Hospital and the University Hospital of Academician Ladislav Dérer is chlorinated and nitrificated before connecting to the public sewerage network. 
Table 1. Characteristics of healthcare facilities.

\begin{tabular}{cccc}
\hline Hospital (SR) & Number of Beds & Equipment Type & Recipient \\
\hline Psychiatric Clinic in Oščadnica (PC) & & outpatient care & River Oščadničanka \\
National Cancer Institute of St. & 198 & hospital with outpatient care & \\
Elizabeth (NCISE) & 875 & hospital with outpatient care & Public sewerage network \\
University Hospital in Ružinov & 635 & hospital with outpatient care & \\
University Hospital of Academician & 397 & hospital with outpatient care & \\
Ladislav Dérer & 222 & hospital with outpatient care & \\
Children's Faculty Hospital & Number of beds & Equipment type & Recipient \\
Hospital in Malacky & & ambulance & \\
\hline Hospital (CZ) & 350 & hospital with outpatient care & Public sewerage network \\
\hline Policlinic in Rožnov pod Radhoštěm & 190 & hospital with outpatient care & \\
Hospital in Vsetín & 450 & palliative and outpatient care & \\
Hospital in Valašské Meziř́̌́ći (HVM) & &
\end{tabular}

\subsection{The Occurrence of ATB-Resistant Coliform Bacteria in HEs}

For coliform bacteria and E. coli enumeration in wastewater samples collected from healthcare facilities, a diagnostic medium-Chromocult Coliform agar (VWR Chemicals, USA) stated by ISO 9308 (2014) was used [14]. Samples of HEs were diluted and subsequently inoculated on ATB agar plates with the same procedure as in the case of influent wastewaters described in the study of Lépesová et al. (2018) [15]. Ampicillin (AMP), gentamicin (GEN), ciprofloxacin (CIP) and chloramphenicol (CMP) resistance of coliform bacteria was tested in concentrations defined by the European Committee on Antimicrobial Susceptibility Testing (EUCAST) for the European Union [16] as well as by the Clinical Laboratory Standards Institute (CLSI) for the United States [17]. Tetracycline (TET)-resistance was studied only according to the CLSI since EUCAST does not provide resistance breakpoints [17].

All experiments were performed in tree parallels and were repeated three times. Cultivation conditions of coliform bacteria were $37^{\circ} \mathrm{C}, 24 \mathrm{~h}$.

\subsection{Isolation and Identification of Resistant Coliform Bacteria}

Coliform bacteria showing resistance to applied ATBs were isolated by streak plate method on Mueller Hinton agar (MH) (Biolife, Italy) and incubated at $37^{\circ} \mathrm{C}$ for $24 \mathrm{~h}$. After obtaining separate colonies of pure cultures, identification via a Matrix-Assisted Laser Desorption/Ionization-Time of Flight (MALDI-TOF) mass spectrometer according to Lépesová et al. (2018) was performed [15]. Briefly, fresh bacterial culture was spotted onto a steel target plate (Bruker Daltonics Inc., Billerica, MA) and dried at room temperature. The MALDI-TOF $\alpha$-cyano-4-hydroxycinnamic acid matrix was prepared daily as a saturated solution in 50\% acetonitrile and $2.5 \%$ trifluoroacetic acid (TFA). The sample to be analyzed was consequently spotted with $1 \mu \mathrm{L}$ of matrix solution. Samples were evaluated by use of an AutoFlex I TOF-TOF apparatus (Bruker Daltonics Inc., Billerica, MA) in linear positive-ion mode across the $\mathrm{m} / \mathrm{z}$ range of 2000 to 20,000 with gating of ions below $\mathrm{m} / \mathrm{z} 400$ and a delayed extraction time of $450 \mathrm{~ns}$. Each spot was measured by using 2000 laser shots at $25 \mathrm{~Hz}$ in groups of 50 shots per sampling area of the spot. The data sampling rate was $0.5 \mathrm{GHz}$. Each plate was calibrated by using a Bacterial Test Standard (Bruker Daltonics). Spectra were analyzed by using MALDI BioTyper software (v 2.0) (BioTyper Library v 3.0; Bruker Daltonics), a proprietary algorithm for spectral pattern matching resulting in a logarithmic score from 0 to 3 . Previous work using discrete bacterial colonies determined that a score of $>1.9$ indicates species identification, a score of 1.7 to 1.9 indicates genus identification, and a score of $<1.7$ indicated no identification. 


\subsection{ATB Susceptibility Detection}

\subsubsection{Macro-Dilution Method Assay}

In resistant coliform bacteria, except E. coli and Klebsiella spp., isolated from hospital wastewaters, the susceptibility to various ATBs including AMP, ceftazidim (CAZ), meropenem (MER), GEN, CIP, CMP and TET was detected by a plate dilution drop method according to Lépesová et al. (2018) [15]. However, E.coli and Klebsiella spp. are frequent and typical producers of ESBLs and carbapenemases, and for these strains wider antibiotic spectrum was applied (see Section 2.4.2).

\subsubsection{Microtiter Plate Assay}

In case of isolates identified as E. coli and Klebsiella spp. a commercial microtiter plate assay for resistance profile detection was used. During the method, the manufacturer's manual was followed. MicrolatestMIC test (Erba Lachema, Czech Republic) contains 24 ATBs divided into two plates G I and G II for each tested bacterial isolate. While the plate G I detects resistance to AMP, ampicillin/sulbactam (AMS), aztreonam (AZT), amikacin (AMK), GEN, CIP, CMP, colistin (COL), trimethoprim/sulfamethoxazole (T/S), TET, cefazolin (CFZ) and cefuroxime (CXM), plate G II serves to determine the sensitivity of isolates to piperacillin (PIP), piperacillin/tazobactam (PIT), tobramycin (TOB), netilmicin (NET), tigecycline (TGC), CAZ, cefotaxime (CTX), cefoperazone (CPZ), cefoperazone/sulbactam (CPS), cefepime (CEP), ertapenem (ERT) and MER. Microtiter plates with inoculum were incubated statically at $37^{\circ} \mathrm{C}$ for $16-20 \mathrm{~h}$ and the growth of bacterial cultures was evaluated spectrophotometrically $(\lambda=630 \mathrm{~nm})$ using a plate reader (BioTek, US). The results were assessed according to the manufacturer's manual.

\subsection{Double Disk Synergy Test for the Production of ESBLS}

Inoculum $(2 \mathrm{~mL})$ of $24 \mathrm{~h}$ bacterial culture in physiological saline was prepared to a final density of $0.5 \mathrm{McF}$ arland scale. For each tested isolate, a pair of $\mathrm{MH}$ agar plates with and without oxacillin (c $=128 \mathrm{mg} / \mathrm{L}$ ) (Sigma Aldrich, Germany) was prepared. Agar plates were inoculated with prepared bacterial suspensions via sterile cotton sticks on which the ATB disks of amoxicillin/clavulanic acid (AMC), AZT, CAZ, CTX and CEP (Oxoid, UK) were applied according to the scheme published in the study of Hrabák et al. (2008) [18]. After cultivation for $24 \mathrm{~h}$ at $37^{\circ} \mathrm{C}$ the growth of inhibitory zones around the applied ATB disks was observed.

\subsection{Ethidium Bromide (EtBr) Agar Cartwheel Method for Efflux Pumps Overproduction}

Overnight cultures (16-18 h) of ATB-resistant coliform isolates in MH broth were prepared. The bacterial suspension density was again adjusted to $0.5 \mathrm{McF}$ arland in physiological saline and $\mathrm{MH}$ agar plates with EtBr (Serva, Germany) at a concentration $2.5 \mathrm{mg} . \mathrm{L}^{-1}$ were prepared. Each culture of resistant coliform bacteria was seeded onto the surface of $\mathrm{EtBr}$ agar plates with a sterile cotton stick. Incubation of agar plates took place for $16-18 \mathrm{~h}$ at $37^{\circ} \mathrm{C}$ and the activity of the efflux pumps was subsequently detected after UV irradiation [19].

\subsection{Biofilm Detection Assay}

The method for biofilm detection has been previously described in the study of Lépesová et al. (2018) [15]. A quantitative assessment of biofilm formation was detected by measuring the absorbance of biofilm eluate at $570 \mathrm{~nm}$ using a plate reader (BioTek, US).

Based on the absorbance values measured on a spectrophotometer the tested isolates were included among weak, medium, strong, and very strong producers of bacterial biofilm according to the scale developed by Taniguchi et al. (2009) [20]. The scale value intervals were previously described in the study of Lépesová et al. (2018) [15]. Pseudomonas aeruginosa (CCM 3955) from the Czech Collection of Bacterial Strains in Brno served as a positive control for the detection of biofilm formation ability by resistant isolates of coliform bacteria. The experiment run in six parallels and was repeated three times. 


\subsection{Antibiotic Resistance Gene Detection}

\subsubsection{Multiplex PCR Assay for ESBL Gene Detection}

The reaction mixture for multiplex PCR was prepared by mixing of primers (Metabion International AG, Germany) (Table 2) and deionized sterile water for molecular purposes (5 Prime, Germany) in a final volume of $25 \mu \mathrm{L}$. Other reagents such as the mix of the deoxyribonucleotide triphosphates (dNTPs), PCR buffer and the Hot Start Taq DNA Polymerase with $\mathrm{MgCl}_{2}$ were added to the reaction mixture as a commercial Multiplex Master Mix (MPMX) (Biotechrabbit, Germany) preparation. One colony of each resistant coliform isolate was suspended in the reaction mixture before initial denaturation $\left(94^{\circ} \mathrm{C}\right)$. MPMX in a total volume of $25 \mu \mathrm{L}$ was added after the initial denaturation and incubation to $72{ }^{\circ} \mathrm{C}$ to each sample.

Table 2. Oligonucleotides used in this study.

\begin{tabular}{|c|c|c|c|c|c|}
\hline & Primer & $\begin{array}{c}\text { Sequence } \\
\left(5^{\prime} \text { to } 3^{\prime} \text { Direction) }\right.\end{array}$ & $\begin{array}{l}\text { Primer Volume } \\
(\mu \mathrm{L})\end{array}$ & $\begin{array}{c}\text { Amplicon Size } \\
\text { (bp) }\end{array}$ & Source \\
\hline \multirow{6}{*}{ Multiplex I } & TEM_fwd & CATTTCCGTGTCGCCCTTATTC & 1 & \multirow{2}{*}{800} & \multirow{10}{*}{ [21] } \\
\hline & TEM_rev & CGTTCATCCATAGTTGCCTGAC & 1 & & \\
\hline & SHV_fwd & AGCCGCTTGAGCAAATTAAAC & 1 & & \\
\hline & SHV_rev & ATCCCGCAGATAAATCACCAC & 1 & 713 & \\
\hline & OXA_fwd & GGCACCAGATTCAACTTTCAAG & 1 & & \\
\hline & OXA_rev & GACCCCAAGTTTCCTGTAAGTG & 1 & 564 & \\
\hline \multirow{4}{*}{ Multiplex II } & CTXMGp1_fwd & TTAGGAARTGTGCCGCTGYA $^{a}$ & 0.25 & \multirow[b]{2}{*}{688} & \\
\hline & CTXMGp1_rev & CGATATCGTTGGTGGTRCCAT a & 0.25 & & \\
\hline & CTXMGp2_fwd & CGTTAACGGCACGATGAC & 0.25 & \multirow{2}{*}{404} & \\
\hline & CTXMGp2_rev & CGATATCGTTGGTGGTRCCAT $^{\mathrm{a}}$ & 0.25 & & \\
\hline \multirow{4}{*}{ Single PCR } & CTXM8/25_fwd & AACRCRCAGACGCTCTAC ${ }^{a}$ & 0.25 & \multirow{2}{*}{326} & \\
\hline & CTXM8/25_rev & TCGAGCCGGAASGTGTYAT a & 0.25 & & \\
\hline & CTXM15_fwd & CACACGTGGAATTTAGGGACT & 1 & \multirow{2}{*}{995} & \multirow{2}{*}{ [22] } \\
\hline & CTXM15_rev & GCCGTCTAAGGCGATAAACA & 1 & & \\
\hline \multirow{4}{*}{ Tet Multiplex } & TetA_fwd & GCTACATCCTGCTTGCCTTC & 0.5 & \multirow{2}{*}{210} & \multirow{4}{*}[23]{} \\
\hline & TetA_rev & CATAGATCGCCGTGAAGAGC & 0.5 & & \\
\hline & TetE_fwd & AAACCACATCCTCCATACGC & 0.5 & \multirow{2}{*}{278} & \\
\hline & TetE_rev & AAATAGGCCACAACCGTCAG & 0.5 & & \\
\hline
\end{tabular}

\subsubsection{Single PCR Assay for ESBL Gene Detection}

The reaction mixture for single PCR was prepared in a final volume of $50 \mu \mathrm{L}$ by mixing of $5 \mu \mathrm{L}$ of $10 \times$ concentrated buffer solution of $\mathrm{MgCl}_{2}$ for Taq polymerase $\left(100 \mathrm{mmol} \cdot \mathrm{L}^{-1}\right.$, Tris $/ \mathrm{HCl}, \mathrm{pH} 9 \mathrm{pri} 25^{\circ} \mathrm{C}$, $500 \mathrm{mmol} \cdot \mathrm{L}^{-1} \mathrm{KCl}$ a $1 \%$ Triton X-100), $1 \mu \mathrm{L}$ of $0.2 \mathrm{mmol} \cdot \mathrm{L}^{-1} \mathrm{dNTPs}, 42 \mu \mathrm{L}$ of deionized sterile water for molecular purposes, 50-100 ng of genomic DNA and defined volume of each primers according to Table 2. As in case of MPMX, $1 \mathrm{U}$ Taq DNA polymerase at a volume of $0.5 \mu \mathrm{L}$ was added to the reaction mixture after the initial denaturation $\left(94^{\circ} \mathrm{C}\right)$.

\subsubsection{PCR Conditions}

PCR was performed under the following conditions: initial denaturation $\left(94^{\circ} \mathrm{C} / 20 \mathrm{~min}\right)$, denaturation (94 ${ }^{\circ} \mathrm{C} / 40 \mathrm{~s}$ ), annealing (55 ${ }^{\circ} \mathrm{C}$ for Multiplex I reaction and bla $\mathrm{CTX-M-15}, 60^{\circ} \mathrm{C} / 1 \mathrm{~min}$ for Multiplex II reaction and $\left.b l a_{C T X-M-8 / 25}\right)$, extension $\left(72{ }^{\circ} \mathrm{C} / 1 \mathrm{~min}\right)$ and final extension $\left(72{ }^{\circ} \mathrm{C} / 10 \mathrm{~min}\right)$ in 35 cycles in a thermocycler (Mastercycler personal, Eppendorf, Germany). The size of PCR products was detected by $1.5 \%(w / v)$ agarose gel electrophoresis.

\subsubsection{Multiplex PCR Assay for Tet Genes Detection}

The multiplex PCR reaction mixture for detection of tet $A$ and tet $E$ genes encoding the overproduction of tetracycline efflux pumps was prepared as described above. However, each of the primers was applied at a volume of $0.5 \mu \mathrm{L}$ (Table 2). PCR was performed under the same conditions as 
in the case of ESBL gene detection with an annealing temperature of $55^{\circ} \mathrm{C}$. In the last step the PCR products were visualized by gel electrophoresis $(1.5 \%(w / v)$ agarose gel).

\section{Results and Discussion}

\subsection{The occurrence of ATB-Resistant Coliform Bacteria in Wastewaters from Healthcare Facilities}

Studies show that conventional wastewater treatment renders limited results in terms of ATB and ATB-resistant bacteria and gene removal. Additionally, it might even increase the concentration of certain ATB resistance genes in wastewater which flow further into the environment [24-28]. Due to these facts, the quantification of ATB-resistant bacteria in 18 wastewater samples collected from 10 hospitals and healthcare facilities was performed (Table 1). Monitoring was focused on fecal indicator bacteria in HEs because some representatives of these genera are characterized by MDR and associated with life-threatening infections [1].

The total number of coliform bacteria ranged up to $7.18 \mathrm{log} \mathrm{CFU} \cdot \mathrm{mL}^{-1}$ of which $4.49 \mathrm{log} \mathrm{CFU} \cdot \mathrm{mL}^{-1}$ was represented by E. coli (Table 3). In our previous work the number of coliform bacteria in influent wastewater from three Slovak and three Czech WWTPs ranged from 3.02 to $4.94 \log \mathrm{CFU} \cdot \mathrm{mL}^{-1}$ [29]. The number of coliform bacteria in some samples of HE is much higher, so this strengthens the fact that HE can significantly contribute to the spread of different bacteria.

Table 3. Number of total and resistant coliform bacteria (E. coli) in hospital effluents (HEs).

\begin{tabular}{ccc}
\hline & $\begin{array}{c}\text { CFB } \\
(\log \text { CFU·mL }\end{array}$ & $\begin{array}{c}\text { EC } \\
(\mathbf{l o g} \text { CFU·mL }\end{array}$ \\
\hline Total & ND-7.18 \pm 0.32 & ND-4.49 \pm 0.15 \\
AMP (EU) & ND-7.17 \pm 0.41 & ND-4.37 \pm 0.31 \\
GEN (EU) & ND-6.59 \pm 0.18 & ND-3.81 \pm 0.16 \\
CIP (EU) & ND-6.39 \pm 0.21 & ND-3.69 \pm 0.09 \\
CMP (EU) & ND-5.41 \pm 0.14 & ND-2.86 \pm 0.06 \\
AMP (US) & ND-7.17 \pm 0.12 & ND-4.35 \pm 0.11 \\
GEN (US) & ND-6.45 \pm 0.22 & ND-3.63 \pm 0.08 \\
CIP (US) & ND-5.79 \pm 0.17 & ND-3.59 \pm 0.14 \\
CMP (US) & ND-5.00 \pm 0.25 & ND-2.62 \pm 0.19 \\
TET (US) & ND-5.86 \pm 0.09 & ND-3.73 \pm 0.07 \\
\hline
\end{tabular}

CFB—coliform bacteria, EC-E. coli, AMP—ampicillin, GEN—gentamicin, CIP-ciprofloxacin, CMP—chloramphenicol, TET-tetracycline, ND—not detected, EU—resistance breakpoints according to the European Committee on Antimicrobial Susceptibility Testing (EUCAST), US - resistance breakpoints according to the Clinical Laboratory Standards Institute (CLSI).

Resistance of coliform bacteria was detected against five types of ATBs of different classes including $\beta$-lactams, aminoglycosides, FQs, amphenicols and tetracyclines. AMP as $\beta$-lactam ATB was selected due to frequent prescription in Slovakia. Both GEN (aminoglycoside) and CIP (FQ) may be present in higher levels due to their frequent use in the treatment of infections caused by Gram-negative bacteria in the community as well as in the hospital sector [30]. The use of CMP is currently limited, but bacterial strains with resistance to this ATB persist due to the possible mechanisms of cross-resistance [31].

In variable samples of HEs different numbers of resistant coliforms were detected. In general, the highest resistance rate was noticed against AMP, which relates to its frequent use in both the Slovak as well as the Czech Republic [30]. Additionally, according to Magiorakos et al. (2012) many strains included in the group of coliform bacteria are equipped with intrinsic resistance to this ATB [32]. In the case of E. coli AMP resistance is acquired. However, AMP is rapidly degraded during the wastewater treatment and the prevalence of AMP-resistant bacteria in wastewaters is related to the horizontal transfer of genes encoding the production of $\beta$-lactamases [31].

Similarly, Le et al. (2016) [3] found in HEs high prevalence of coliform bacteria with MDR phenotype. Effluents from the NCISE and the HVM contained a high number of coliform bacteria 
showing resistance to all tested ATBs. Although, the number of beds for hospitalized patients is comparable in both hospitals (Table 1), the number of ATB-resistant coliforms was on average two logarithmic orders higher in the HVM. However, it is important to note that wastewater from the NCISE is pre-treated before reaching the public sewerage network (Table 1). The high number of AMP, GEN and CIP resistant coliform bacteria was also observed in effluent samples taken from specialized palliative Hospice Citadela as well as from the Psychiatric Clinic (PC) in Oščadnica. Within the group of coliform bacteria, MDR E. coli were detected in the effluent of the NCISE, the PC and in two Czech hospitals (HVM and Vsetín).

\subsection{Identification and Susceptibility of ATB-Resistant Coliform Bacteria Isolates}

Nowadays, a steady increase in the number of ATB-resistant bacteria as well as ARGs complicating the treatment of both human and animal pathogens, not only in the field of clinical medicine but also in native isolates originating from the contaminated aqueous environment, was monitored [33,34]. Thirty-five strains of ATB-resistant coliform bacteria were isolated from two sample HEs-NCISE (18 strains) and PC in Oščadnica (17 strains). The majority was identified as E. coli (54\%) followed by Lelliottia amnigena (17\%), Citrobacter freundii (14\%) and Enterobacter cloacae (6\%). The remaining isolates were included in the genus of Citrobacter (C. gillenii-3\%) and Klebsiella (K. variicola-3\%, K. pneumoniae-3\%).

When assessing the ATB susceptibility profile of isolates, the intrinsic AMP, AMS and CFZ resistance of $C$. freundii and E. cloacae as well as the intrinsic AMP resistance of Klebsiella spp. was considered [32]. Table 4 summarizes the ATB susceptibility profile of isolates.

Table 4. Susceptibility and multidrug resistant (MDR) phenotype of resistant isolates of coliform bacteria.

\begin{tabular}{|c|c|c|c|c|c|c|}
\hline & & \multicolumn{5}{|c|}{ Number of resistant isolates } \\
\hline & & E. coli & Citrobacter spp. & L. amnigena & E. cloacae & Klebsiella spp. \\
\hline \multicolumn{2}{|c|}{ Number of isolates } & 19 & 6 & 6 & 2 & 2 \\
\hline \multirow{24}{*}{ Antibiotics } & AMP & 19 & INR & 6 & INR & INR \\
\hline & AMS & 14 & - & - & - & 2 \\
\hline & CFZ & 13 & - & - & - & 2 \\
\hline & CXM & 10 & - & - & - & 2 \\
\hline & $\mathrm{AZT}$ & 7 & - & - & - & 1 \\
\hline & GEN & 16 & 6 & 2 & 1 & 2 \\
\hline & AMK & 7 & - & - & - & 0 \\
\hline & COL & 3 & - & - & - & 1 \\
\hline & $\mathrm{T} / \mathrm{S}$ & 8 & - & - & - & 2 \\
\hline & CIP & 9 & 5 & 5 & 1 & 2 \\
\hline & CMP & 7 & 5 & 2 & 1 & 1 \\
\hline & TET & 14 & 6 & 5 & 2 & 2 \\
\hline & PIP & 17 & - & - & - & 2 \\
\hline & PIT & 6 & - & - & - & 1 \\
\hline & CTX & 9 & - & - & - & 1 \\
\hline & CAZ & 12 & 6 & 6 & 2 & 1 \\
\hline & $\mathrm{CPZ}$ & 8 & - & - & - & 2 \\
\hline & CPS & - & - & - & - & - \\
\hline & CEP & 12 & - & - & - & 1 \\
\hline & MER & 0 & 0 & 0 & 0 & 0 \\
\hline & ERT & 3 & - & - & - & 0 \\
\hline & TGC & 0 & - & - & - & 0 \\
\hline & NET & 14 & - & - & - & 1 \\
\hline & TOB & 15 & - & - & - & 1 \\
\hline \multicolumn{2}{|l|}{$\%$ MDR } & 79 & 100 & 100 & 100 & 100 \\
\hline
\end{tabular}

AMP-ampicillin, AMS-ampicillin/sulbactam, CFZ-cefazolin, CXM-cefuroxime, AZT-aztreonam, GEN-gentamicin, AMK-amikacin, COL-colistin, T/S-trimethoprim/sulfamethoxazole, CIP-ciprofloxacin, CMP-chloramphenicol, TET-tetracycline, PIP-piperacillin, PIT-piperacillin/tazobactam, CTX-cefotaxime, CAZ-ceftazidime, CPZ-cefoperazone, CPS-cefoperazone/sulbactam, CEP-cefepime, MER-meropenem, ERT-ertapenem, TGC-tigecycline, NET-netilmicin, TOB-tobramycin. INR-intrinsic resistance, MDR-multidrug-resistance. 
More than $50 \%$ of $E$. coli isolates were resistant to 11 tested ATBs (Table 4). A high rate of resistance to the penicillin-type of ATB (AMP, PIP) as well as to their combination with $\beta$-lactam inhibitors was also observed (Table 4). Isolates from the NCISE showed CTX, CAZ, CEP, CFZ and CXM resistance. In E. coli isolated from the PC only CFZ and CAZ resistance was observed. Conte et al. (2017) have also isolated MDR bacterial strains identified mainly as E. coli, K. pneumoniae and K. oxytoca from hospital wastewaters in Brazil showing high resistance to CTX as well as CAZ [35]. Resistance to these two antibiotics predicts ESBL production typical for bacteria present in HEs [36]. The increasing MDR bacteria occurrence (especially in hospitals) leads to frequent use of last-choice ATBs such as carbapenems or COL resulting in the development of resistance [30]. Although, resistance of E. coli to MER was not detected, $16 \%$ of E.coli isolates were resistant to ERT and COL. ATB resistant K. pneumoniae is the second most dangerous pathogen associated with severe and long-term infections leading to high morbidity and mortality [37]. According to the EARS-Net reports in 2016, up to one third of K. pneumoniae isolates were resistant to at least one of the controlled groups of ATBs including FQs, third generation cephalosporins, aminoglycosides and carbapenems. The combined resistance to multiple ATBs was also routinely described [30] as has been shown in the case of an isolate of K. pneumoniae that was resistant to COL, NET, TOB as well as to AZT, CAZ, CTX and CEP.

Hospital wastewater offers an environment suitable for the various antibiotic resistance genes to exchange [3]. These facts are also highlighted by results obtained in this study according to which up to $70 \%$ of coliforms isolated from the HEs were MDR (Table 4 ).

\subsection{Selected Mechanisms of ATB Resistance in Isolates}

\subsubsection{Detection of Efflux Pumps Overproduction}

Efflux pumps overproduction is the most common reason for the cross-resistance to different ATB [31]. A significant number of E. coli isolated from both HEs showed overproduction of efflux pumps $(74 \%)$ together with the MDR phenotype (86\%). Half of the isolates identified as L. amnigena and C. freundii as well as the isolate K. variicola were also characterized by increased efflux (Table 5).

Table 5. Characterization of antibiotic resistant coliform bacteria isolated from HEs.

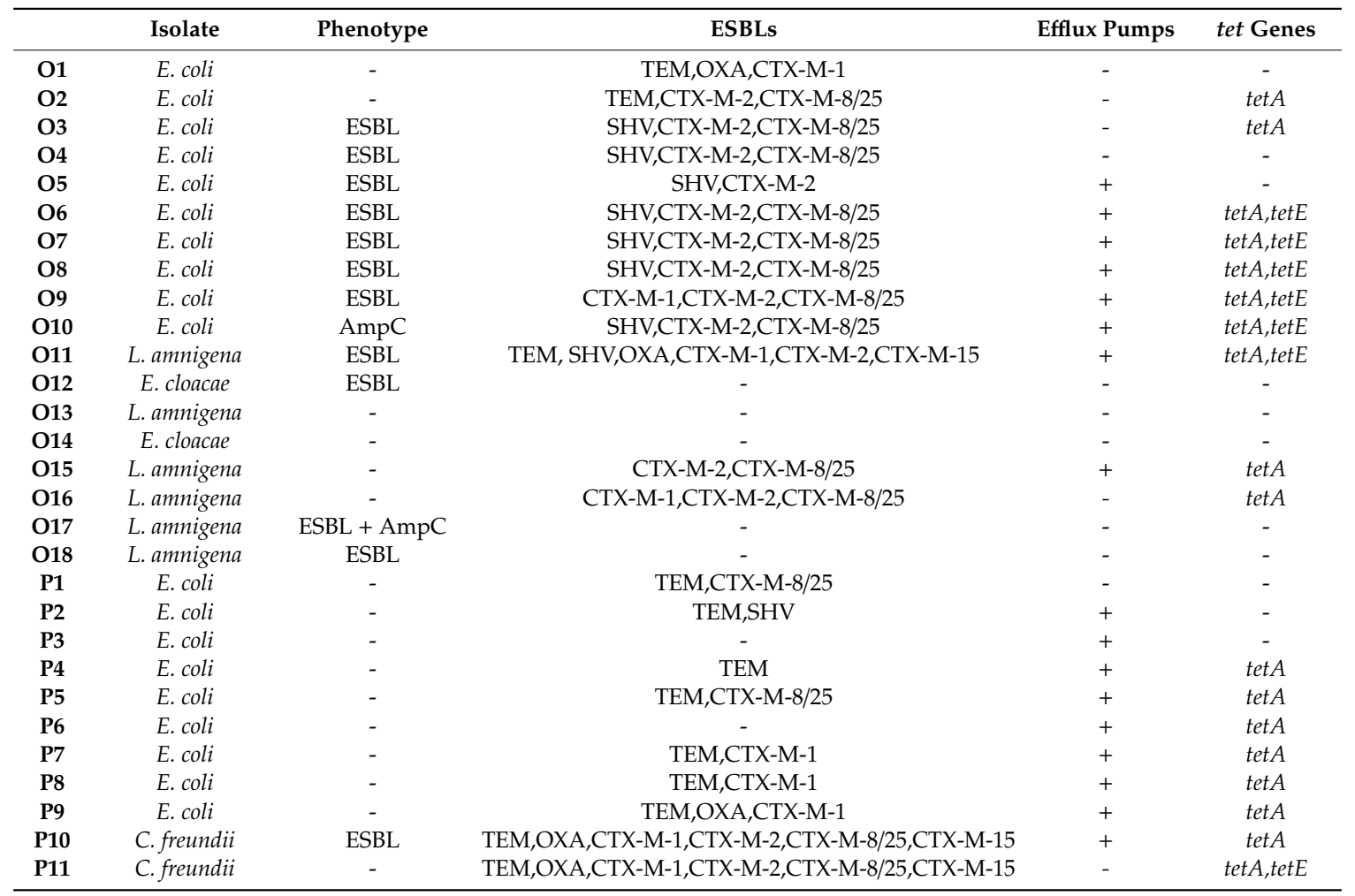


Table 5. Cont.

\begin{tabular}{|c|c|c|c|c|c|}
\hline & Isolate & Phenotype & ESBLs & Efflux Pumps & tet Genes \\
\hline P12 & C. freundii & ESBL & TEM,OХA,CTX-M-1,CTX-M-2,CTX-M-8/25,CTX-M-15 & - & tet $A$, tet $E$ \\
\hline P13 & C. freundii & ESBL & TEM,OХA,CTХ-M-1,CTX-M-2,CTX-M-8/25,CTХ-M-15 & - & tet $A$, tet $E$ \\
\hline P15 & C. gillenii & - & TEM,OXA,CTX-M-8/25 & - & - \\
\hline P16 & K. variicola & - & TEM,SHV,OXA,CTX-M-1,CTX-M-2,CTX-M-15 & + & tet $A$, tet $E$ \\
\hline P17 & K. pneumoniae & - & TEM,SHV,OXA,CTX-M-1 & - & tet $A$ \\
\hline
\end{tabular}

Several studies show that tet $A$ and tet $E$ genes encoding TET efflux pumps are frequently found in all coliform bacteria, especially in E. coli [38-41]. The presence of tet genes was monitored in all isolates (Table 5). The majority of isolates was characterized by the presence of the tet $A$ gene, while half of these isolates contained also tet $E$ gene. In 13 isolates of $E$. coli the presence of $t e t A$ gene was detected. Although Chopra and Roberts (2001) noted the presence of the tetE gene in particular with tetB, tetI, tet $C$ and tet $D$ genes, similarly to Adesoji et al. (2015) the coexistence of this gene with tet $A$ in $5 E$. coli isolates was observed $[39,42]$. All of the isolates identified as C. freundii, L. amnigena, K. pneumoniae and K. variicola acquired tet $A$ gene. Four isolates of $C$. freundii as well as one isolate of L. amnigena and $K$. variicola contained this gene, encoding the increased production of efflux pumps (Table 5).

\subsubsection{Detection of ESBL Production}

Phenotype of ESBL production was observed in seven isolates identified as E. coli as well as in four isolates of C. freundii, two isolates of L. amnigena and one isolate of E. cloacae (Table 5). Similarly, Yamashita et al. (2017) detected a high prevalence of ESBL-producing strains of E. coli in hospital wastewaters and subsequently in the rivers of Japan [43]. The production of the AmpC type of $\beta$-lactamases is also clinically important because their over-expression provides resistance to a wide range of drugs including penicillin, cephalosporins, cefoxitin and inhibitors of $\beta$-lactamases. According to the EUCAST, the most common AmpC producers are E. coli, K. pneumoniae, K. oxytoca and Salmonella enterica [44]. AmpC enzyme production was detected only in one isolate of E. coli from the effluent taken in the NCISE. As a result of mutations in constitutive genes a hyperproduction of chromosomally encoded AmpC $\beta$-lactamases may occur, especially in strains of Enterobacter spp., Citrobacter spp., Serratia spp. and Acinetobacter spp. [45]. Hyperproduction of AmpC in combination with ESBL production was detected in one isolate of L. amnigena from the effluent of the NCISE (Table 5).

Gram-negative bacteria bearing multiple bla genes (e.g., bla $a_{N D M}, b l a_{K P C}, b l a_{C T X-M}$, and $b l a_{S H V}$ ) are increasingly found in hospital wastewaters, together with other common and related ARGs such as qnr (FQ), erm (macrolide), sul (sulfonamides), and tet (TET) [3]. The production of ESBLs encoded by $b l a_{T E M}, b l a_{S H V}$ or $b l a_{C T X-M}$ genes are considered as most frequent among Enterobacteriaceae over the last decade [21,22]. Thirty isolates resistant to AMP and cephalosporin ATBs were screened for the presence of $b l a_{T E M}, b l a_{O X A}$ and $b l a_{S H V}$ genes. TEM-type $\beta$-lactamases are characteristic for E. coli isolates, while SHV enzymes predominate in Klebsiella spp. [46]. Nevertheless, in case of E. coli isolates the presence of the TEM ( 9 isolates) and SHV ( 8 isolates) group of genes was quite similar and the frequency of the occurrence of $b l a_{O X A}$ genes was much lower (two isolates) (Table 5). Another study pointed out the significant presence of both $b l a_{T E M}$ and bla $a_{S H V}$ genes in ESBL-producing E. coli isolated from patients with urinary tract infection [47]. All of these results suggest the presence of high numbers of ARB harboring bla TEM genes in hospital environments. A significant proportion (70\%) of E. coli isolated from the effluent of NCISE possessed a group of bla $a_{S H V}$ genes in the absence of genes encoding TEM-type ESBLs. In the study of Haller et al. (2018) 33 of 94 Gram-negative isolates from HEs in Singapore were also positive for the presence of bla $a_{S H V}$ genes [48]. In all isolates of C. freundii, C. gillenii as well as K. variicola and K. pneumoniae, the presence of genes encoding a group of TEM and OXA $\beta$-lactamases was observed. In accordance with Zhu et al. (2017) bla ${ }_{S H V}$ genes occurred in all isolates of Klebsiella spp. (Table 5) [46]. 
Unlike other ESBLs, the CTX-M family constitutes a complex and non-homogeneous group of enzymes. Nowadays, among all types of ESBLs, CTX-M enzymes are much more widespread in Enterobacteriaceae not only in Europe but also in other parts of the world [21]. In all tested isolates of C. freundii (five isolates) and K. variicola (one isolate) from the effluent of the PC in Oščadnica, the presence of genes encoding the CTX-M-1 and CTX-M-2 group of enzymes was confirmed (Table 5). In addition, isolates of $C$. freundii were characterized also by the presence of bla cephalosporin ATBs in 3 isolates of L. amnigena was encoded by bla CTX-M-1 genes, while two were also possessed by bla $a_{C T X-M-2}$ and bla ${ }_{C T X-M-8 / 25}$ genes. Whereas in the isolate of $C$. gillenii the production of the CTX-M-1 and CTX-M-2 group of enzymes was not encoded, the presence of the bla genes was observed. Among genes encoding CTX-M type of ESBLs, K. pneumoniae possessed only by bla $_{C T X-M-1}$ genes (Table 5). Many studies indicate a higher prevalence of CTX-M-type ESBLs compared to TEM-type enzymes in clinical isolates of $E$. coli $[47,49]$, which was confirmed also in the present work. While the presence of $b l a_{T E M}$ genes was reported only in 9 isolates of $E$. coli, different variants of $b l a_{\text {СТX-M }}$ genes were found in 15 isolates. Specifically, from all 19 tested isolates the highest number (10 isolates) was positive for the presence of $b l a_{C T X-M-8 / 25}$ genes. Conte et al. (2017) also noted a high prevalence of the $b l a_{C T X-M-8}$ gene including to the $b l a_{C T X-M-8 / 25}$ group of genes in ESBL-producing E. coli isolates [35]. CTX-M-8 enzyme was first described in clinical samples in Brazil and subsequently also in environmental samples. Bacteria producing this type of ESBL have been detected only sporadically in hospital settings but have been prevalent among isolates from food-producing animals and chicken meat [35]. The presence of genes encoding the CTX-M-2 group of enzymes was found in nine isolates, while five were positive for the presence of $b l a_{C T X-M-1}$ genes (Table 5).

At the present time, among all the CTX-M-type of ESBLs the most widespread is CTX-M-15, whose production was first described in E. coli [22]. In case of all isolates of $C$. freundii as well as in one isolate of L. amnigena and $K$. variicola. the group of $b l a_{C T X-M-1}$ genes was specifically represented by this gene (Table 5). Memariani et al. (2015) indicate the coexistence of the $b l a_{C T X-M-15}$ gene with other ESBL-encoding genes such as $b l a_{T E M}$ and $b l a_{S H V}$ or even with genes encoding resistance to other ATBs including $q n r$ and $a a c\left(6^{\prime}\right)-I b-c r$ genes [22]. The presence of a gene encoding the CTX-M-15 production was always detected, together with $b l a_{T E M}, b l a_{O X A}$ and $b l a_{C T X-M-2}$ genes, highlighted also in the study of Sun et al. (2018) [50].

\subsection{The Ability of ATB-Resistant Isolates to form Biofilm}

The production of biofilm was observed in all coliform bacteria isolated from HEs. More than half were strong producers of bacterial biofilm. One third of isolates were strong biofilm producers, whereas $20 \%$ were medium producers of biofilm (Table 6). It was assumed that the high proportion of coliform bacteria included among strong and very strong biofilm producers isolated from HEs were derived from patients as well as contaminated catheter surfaces or other devices. Despite efforts to maintain sterility, implantable and prosthetic medical devices can easily become contaminated with bacteria. Bacterial biofilms have been most often identified on urinary catheters, endoscopes, tracheal tubes, or breast implants. According to National Institute of Health, biofilms account for up to $80 \%$ of the total number of microbial infections in humans. Major challenges in treating such infections are their difficult diagnosis as well as a high tolerance of pathogens attached in biofilms to antibiotics [51].

Table 6. Ability of antibiotic resistant coliform bacteria isolated from HEs to form biofilm.

\begin{tabular}{|c|c|c|c|c|c|}
\hline \multirow{2}{*}{$\begin{array}{l}\text { Intensity of Biofilm } \\
\text { Production }\end{array}$} & \multicolumn{5}{|c|}{ Number of Antibiotic Resistant Isolates } \\
\hline & $\begin{array}{l}\text { E. coli } \\
(\mathbf{1 9 )}\end{array}$ & $\begin{array}{c}\text { Citrobacter spp. } \\
\text { (6) }\end{array}$ & $\begin{array}{l}\text { Lelliottia amnigena } \\
\text { (6) }\end{array}$ & $\begin{array}{l}\text { E. cloacae } \\
\text { (2) }\end{array}$ & $\begin{array}{l}\text { Klebsiella spp. } \\
\text { (2) }\end{array}$ \\
\hline low & 0 & 0 & 0 & 0 & 0 \\
\hline medium & 7 & 0 & 0 & 0 & 0 \\
\hline strong & 9 & 1 & 6 & 2 & 1 \\
\hline very strong & 3 & 5 & 0 & 0 & 1 \\
\hline
\end{tabular}




\section{Conclusions}

The hospital environment as well as its wastewaters is of great concern in the development and dissemination of antibiotic resistance. Our data show that effluent wastewater from health care facilities such as hospitals in the Czech and Slovak Republic contains a high number of antibiotic resistant coliform bacteria with MDR phenotype. The majority of antibiotic resistant coliform bacteria isolated from Slovak HEs were MDR with confirmed efflux pump overproduction. The alarming fact is that these strains also produce ESBL and possess a combination of two or more antibiotic resistance genes which can be transferred to antibiotic susceptible bacteria in municipal sewerage. Moreover, the majority of isolates are strong biofilm producers, so they can survive, multiply and disseminate antibiotic resistance genes attached to sewerage walls.

Author Contributions: Conceptualization, K.L.; Data curation, T.M.; Formal analysis, P.O.; Investigation, K.C.; Methodology, M.K.; Supervision, L.B. All authors have read and agreed to the published version of the manuscript.

Funding: This work was supported by the Slovak Research and Development Agency (grant no. APVV-16-0171 and APVV-19-0094), the Scientific Grant Agency VEGA (grant no. VEGA 1/0096/17) and by a project for the building of infrastructure for the modern research of civilization diseases (ITMS 26230120006).

Conflicts of Interest: Lucia Bírošová has received research grant from the Slovak Research and Development Agency (grant no. APVV-16-0171), the Scientific Grant Agency VEGA (grant no. VEGA 1/0096/17). The authors declare that there are no conflicts of interest. Other authors declare no conflict of interest.

\section{References}

1. Barancheshme, F.; Munir, M. Strategies to combat antibiotic resistance in the wastewater treatment plants. Front. Microbiol. 2018, 8, 1-12. [CrossRef] [PubMed]

2. Mackul'ak, T.; Nagyová, K.; Fáberová, M.; Grabic, R.; Koba, O.; Gál, M.; Birošová, L. Utilization of Fenton-like reaction for antibiotics and resistant bacteria elimination in different parts of WWTP. Environ. Toxicol. Pharmacol. 2015, 40, 492-497. [CrossRef] [PubMed]

3. Le, T.H.; Ng, C.; Chen, H.; Yi, X.Z.; Koh, T.H.; Barkham, T.M.; Zhou, Z.; Gin, K.Y. Occurrences and characterization of antibiotic-resistant bacteria and genetic determinants of hospital wastewater in a tropical country. Antimicrob. Agents Chemother. 2016, 60, 7449-7456. [CrossRef] [PubMed]

4. Jutkina, J.; Rutgersson, C.; Flach, C.F.; Joakim Larsson, D.G. An assay for determining minimal concentrations of antibiotics that drive horizontal transfer of resistance. Sci. Total Environ. 2016, 548-549, 131-138. [CrossRef] [PubMed]

5. Hocquet, D.; Muller, A.; Bertrand, X. What happens in hospitals does not stay in hospitals: Antibiotic-resistant bacteria in hospital wastewater systems. J. Hosp. Infect. 2016, 93, 395-402. [CrossRef]

6. Islam, M.A.; Islam, M.; Hasan, R.; Hossain, M.I.; Nabi, A.; Rahman, M.; Goessens, W.H.F.; Endtz, E.P.; Boehm, A.B.; Faruque, S.M. Environmental spread of New Delhi metallo- $\beta$-lactamase-1-producing multidrug-resistant bacteria in Dhaka, Bangladesh. Appl. Environ. Microbiol. 2017, 83, e00793-17. [CrossRef]

7. Lamba, M.; Graham, D.W.; Ahammad, S.Z. Hospital wastewater releases of carbapenem-resistance pathogens and genes in urban India. Environ. Sci. Technol. 2017, 51, 13906-13912. [CrossRef]

8. Mackul'ak, T.; Grabic, R.; Špalková, V.; Belišová, N.; Škulcová, A.; Slavík, O.; Horký, P.; Gál, M.; Filip, J.; Híveš, J.; et al. Hospital wastewaters treatment: Fenton reaction vs. BDDE vs. ferrate(VI). Environ. Sci. Pollut. Res. Int. 2019, 26, 31812-31821. [CrossRef]

9. Tasca, A.L.; Clematis, D.; Stefanelli, E.; Panizza, M.; Puccini, M. Ciprofloxacin removal: BDD anode coupled with solid polymer electrolyte and ultrasound irradiation. J. Water Process. Eng. 2020, 33, 101074. [CrossRef]

10. World Health Organisation, WHO. WHO Publishes List of Bacteria for which New Antibiotics are Urgently Needed. 27 February 2017, News Release, Geneva. Available online: https://www.who.int/news-room/ detail/27-02-2017-who-publishes-list-of-bacteria-for-which-new-antibiotics-are-urgently-needed (accessed on 25 October 2018).

11. Pilmis, B.; Cattoir, V.; Lecointe, D.; Limelette, A.; Grall, I.; Mizrahi, A.; Marcade, G.; Poilane, I.; Guillard, T.; Bourgeois Nicolaos, N.; et al. Carriage of ESBL-producing Enterobacteriaceae in French hospitals: The PORTABLSE study. J. Hosp. Infect. 2018, 98, 247-252. [CrossRef] 
12. Sabir, N.; Ikram, A.; Zaman, G.; Satti, L.; Gardezi, A.; Ahmed, A.; Ahmed, P. Bacterial biofilm-based catheter-associated urinary tract infections: Causative pathogens and antibiotic resistance. Am. J. Infect. Control. 2017, 45, 1101-1105. [CrossRef] [PubMed]

13. Flemming, H.C.; Wingender, J.; Szewzyk, U.; Steinberg, P.; Rice, S.A.; Kjelleberg, S. Biofilms: An emergent form of bacterial life. Nat. Rev. Microbiol. 2016, 14, 563-575. [CrossRef] [PubMed]

14. International Organization for Standardization. ISO 9308-1:2014. Water Quality_Enumeration of Escherichia Coli and Coliform Bacteria-Part 1: Membrane Filtration Method for Waters with Low Bacterial Background Flora; International Organization for Standardization: Geneva, Switzerland, 2014.

15. Lépesová, K.; Kraková, L.; Pangallo, D.; Medved’ová, A.; Olejníková, P.; Mackul'ak, T.; Tichý, J.; Grabic, R.; Birošová, L. Prevalence of antibiotic resistant coliform bacteria, Enterococcus spp. and Staphylococcus spp. in wastewater sewerage biofilm. J. Glob. Antimicrob. Resist. 2018, 14, 145-151. [CrossRef] [PubMed]

16. European Committee on Antimicrobial Susceptibility Testing, EUCAST. Breakpoint Tables for Interpretation of MICs and Zone Diameters. Version 8.0 Valid from 2018-01-01; EUCAST: Växjö, Sweden, 2018; pp. 1-95.

17. Clinical and Laboratory Standards Institute, CLSI. Performance Standards for Antimicrobial Susceptibility Testing, 27th ed.; CLSI: Wayne, PA, USA, 2017; pp. 1-282.

18. Hrabák, J.; Bergerová, T. Detection of Broad-Spectrum Beta-Lactamases and AmpC in Enterobacteriaceae; State Health Institute: Prague, Czech Republic, 2008; pp. 1-9. (In Czech)

19. Martins, M.; McCusker, M.P.; Viveiros, M.; Couto, I.; Fanning, S.; Pagès, J.M.; Amaral, L. A simple method for assessment of MDR bacteria for over-expressed efflux pumps. Open Microbiol. J. 2013, 7, 72-82. [CrossRef]

20. Taniguchi, L.; De Fátima Faria, B.; Rosa, R.T.; De Paula ECarvalho, A.; Gursky, L.C.; Elifio-Esposito, S.L.; Parahitiyawa, N.; Samaranayake, L.P.; Rosa, E.A. Proposal of a low-cost protocol for colorimetric semi-quantification of secretory phospholipase by Candida albicans grown in planktonic and biofilm phases. J. Microbiol. Methods 2009, 78, 171-174. [CrossRef]

21. Dallenne, C.; Da Costa, A.; Decré, D.; Favier, C.; Arlet, G. Development of a set of multiplex PCR assays for the detection of genes encoding important $\beta$-lactamases in Enterobacteriaceae. J. Antimicrob. Chemother. 2010, 65, 490-495. [CrossRef]

22. Memariani, M.; Peerayeh, S.N.; Salehi, T.Z.; Mostafavi, S.K.S. Occurrence of SHV, TEM and CTX-M $\beta$-lactamase genes among enteropathogenic Escherichia coli strains isolated from children with diarrhea. Jundishapur J. Microbiol. 2015, 8, 1-8. [CrossRef]

23. Ng, L.K.; Martin, I.; Alfa, M.; Mulvey, M. Multiplex PCR for the detection of tetracycline resistant genes. Mol. Cell. Probes 2001, 15, 209-215. [CrossRef]

24. Szczepanowski, R.; Linke, B.; Krahn, I.; Gartemann, K.H.; Gützkow, T.; Eichler, W.; Pühler, A.; Scglüter, A. Detection of 140 clinically relevant antibiotic-resistance genes in the plasmid metagenome of wastewater treatment plant bacteria showing reduced susceptibility to selected antibiotics. Microbiology 2009, 155, 2306-2319. [CrossRef]

25. Luo, Y.; Yang, F.; Mathieu, J.; Mao, D.; Wang, Q.; Alvarez, P.J.J. Proliferation of multidrug-resistant New Delhi metallo- $\beta$-lactamase genes in municipal wastewater treatment plants in Northern China. Environ. Sci. Technol. Lett. 2014, 1, 26-30. [CrossRef]

26. Narciso-Da-Rocha, C.; Varela, A.R.; Schwartz, T.; Nunes, O.C.; Manaia, C.M. blaTEM and vanA as indicator genes of antibiotic resistance contamination in a hospital-urban wastewater treatment plant system. J. Glob. Antimicrob. Resist. 2014, 2, 309-315. [CrossRef] [PubMed]

27. Berendonk, T.U.; Manaia, C.M.; Merlin, C.; Fatta-Kassinos, D.; Cytryn, E.; Walsh, F.; Bürgmann, H.; Sørum, H.; Norström, M.; Pons, M.N.; et al. Tackling antibiotic resistance: The environmental framework. Nat. Rev. Microbiol. 2015, 13, 310-317. [CrossRef]

28. Szekeres, E.; Baricz, A.; Chiriac, C.M.; Farkas, A.; Opris, O.; Soran, M.L.; Andrei, A.S.; Rudi, K.; Balcázar, J.L.; Dragos, N.; et al. Abundance of antibiotics, antibiotic resistance genes and bacterial community composition in wastewater effluents from different Romanian hospitals. Environ. Pollut. 2017, 225, 304-315. [CrossRef]

29. Lépesová, K.; Mackul'ak, T.; Birošová, L. The prevalence of antibiotic resistant fecal coliform bacteria in wastewater treatment plants. In Nutrients, Wastewater and Leachate: Testing, Risks and Hazards; Nova Science Publishers: New York, NY, USA, 2018; pp. 57-88. ISBN 9978-1-53613-950-1.

30. European Centre for Disease Prevention and Control. ECDC: Country Overview of Antimicrobial Consumption. Available online: https://www.ecdc.europa.eu/en/antimicrobial-consumption/database/ country-overview (accessed on 25 October 2020). 
31. Birošová, L.; Mackul'ak, T.; Bodík, I.; Ryba, J.; Škubák, J.; Grabic, R. Pilot study of seasonal occurrence and distribution of antibiotics and drug resistant bacteria in wastewater treatment plants in Slovakia. Sci. Total Environ. 2014, 490, 440-444. [CrossRef] [PubMed]

32. Magiorakos, A.P.; Srinivasan, A.; Carey, R.B.; Carmeli, Y.; Falagas, M.E.; Giske, C.G.; Harbarth, S.; Hindler, J.F.; Kahlmeter, G.; Olsson-Liljequist, B.; et al. Multidrug-resistant, extensively drug-resistant and pandrug-resistant bacteria: An international expert proposal for interim standard definitions for acquired resistance. Clin. Microbiol. Infect. 2012, 18, 268-281. [CrossRef] [PubMed]

33. Azzam, M.I.; Ezzat, S.M.; Othman, B.A.; El-Dougdoug, K.A. Antibiotics resistance phenomenon and virulence ability in bacteria from water environment. Water Sci. 2017, 31, 109-121. [CrossRef]

34. Qiao, M.; Ying, G.G.; Singer, A.C.; Zhu, Y.G. Review of antibiotic resistance in China and its environment. Environ. Int. 2018, 110, 160-172. [CrossRef]

35. Conte, D.; Kasuko Palmeiro, J.; Da Silva Nogueira, K.; Rosa De Lima, M.T.; Cardoso, M.A.; Pontarolo, R.; Pontes, F.L.D.; Dalla-Costa, L.M. Characterization of CTX-M enzymes, quinolones resistance determinants, and antimicrobial residues from hospital sewage, wastewater treatment plant, and river water. Ecotoxicol. Environ. Saf. 2017, 136, 62-69. [CrossRef]

36. Maheshwari, M.; Yaser, N.H.; Naz, S.; Fatima, M.; Ahmad, I. Emergence of ciprofloxacin-resistant extended-spectrum $\beta$-lactamase-producing enteric bacteria in hospital wastewater and clinical sources. J. Glob. Antimicrob. Resist. 2016, 5, 22-26. [CrossRef]

37. Daoud, Z.; Salem-Sokhn, E.; Dahdouh, E.; Irani, J.; Matar, G.M.; Doron, S. Resistance and clonality in Escherichia coli and Klebsiella spp. and relationship with antibiotic consumption in major Lebanese hospital. J. Glob. Antimicrob. Resist. 2017, 11, 45-51. [CrossRef]

38. Olowe, O.A.; Idris, O.J.; Taiwo, S.S. Prevalence of tet genes mediating tetracycline resistance in Escherichia coli clinical isolates in Osun State, Nigeria. Eur. J. Microbiol. Immunol. 2013, 3, 135-140. [CrossRef] [PubMed]

39. Adesoji, A.T.; Ogunjobi, A.A.; Olatoye, I.O.; Douglas, D.R. Prevalence of tetracycline resistance genes among multi-drug resistant bacteria from selected water distribution systems in southwestern Nigeria. Ann. Clin. Microbiol. Antimicrob. 2015, 14, 1-8. [CrossRef] [PubMed]

40. Møller, T.S.B.; Overgaard, M.; Nielsen, S.S.; Bortolaia, V.; Sommer, M.O.A.; Guardabassi, L.; Olsen, J.E. Relation between tetR and tet $A$ expression in tetracycline resistant Escherichia coli. BMC Microbiol. 2016, 16, 1-8. [CrossRef] [PubMed]

41. Varela, A.R.; Andre, S.; Nunes, O.C.; Manaia, C.M. Insights into the relationship between antimicrobial residues and bacterial populations in a hospital-urban wastewater treatment plant system. Water Res. 2014, 54, 327-336. [CrossRef] [PubMed]

42. Chopra, I.; Roberts, M. Tetracycline antibiotics: Mode of action, applications, molecular biology, and epidemiology of bacterial resistance. Microbiol. Mol. Biol. Rev. 2001, 65, 232-260. [CrossRef]

43. Yamashita, N.; Katakawa, Y.; Tanaka, H. Occurrence of antimicrobial resistance bacteria in the Yodo River basin, Japan and determination of beta-lactamases producing bacteria. Ecotoxicol. Environ. Saf. 2017, 143, 38-45. [CrossRef]

44. European Committee on Antimicrobial Susceptibility Testing, EUCAST. EUCAST Guidelines for Detection of Resistance Mechanisms and Specific Resistances of Clinical and/or Epidemiological Importance; EUCAST: Växjö, Sweden, 2017; pp. 1-43.

45. Thenmozhi, S.; Kannaiyan, M.; Sureshkumar, B.T.; Mickymaray, S. Antibiotic resistance mechanisms of ESBL producing Enterobacteriaceae in clinical field: A review. Int. J. Pure Appl. Biosci. 2014, 2, 207-224.

46. Zhu, M.; Yang, G.; Li, A.; Zong, L.; Dong, Z.; Lu, J.; Zhang, K.; Cheng, C.; Chang, Q.; Wu, X.; et al. Identification and molecular characterization of Escherichia coli bla ${ }_{S H V}$ genes in a Chinese teaching hospital. Gene 2017, 600, 29-35. [CrossRef]

47. Seyedjavadi, S.S.; Goudarzi, M.; Sabzehali, F. Relation between $b l a_{T E M}, b l a_{S H V}$ and $b l a_{C T X-M}$ genes and acute urinary tract infections. J. Acute Dis. 2016, 5, 71-76. [CrossRef]

48. Haller, L.; Chen, H.; Ng, C.H.; Hoang Le, T.; Koh, T.H.; Barkham, T.; Sobsey, M.; Gin, K.Y. Occurrence and characteristics of extended-spectrum $\beta$-lactamase- and carbapenemases-producing bacteria from hospital effluents in Singapore. Sci. Total Environ. 2018, 615, 1119-1125. [CrossRef] 
49. Haghighatpanah, M.; Mozzafari Nejad, A.S.; Mojtahedi, A.; Amirmozafari, N.; Zeighami, H. Detection of extended spectrum $\beta$-lactamase (ESBL) and plasmid-borne bla $a_{C T X-M}$ and $b l a_{T E M}$ genes among clinical strains of Escherichia coli isolated from patients in the north of Iran. J. Glob. Antimicrob. Resist. 2016, 7, 110-113. [CrossRef] [PubMed]

50. Sun, L.; Xu, J.; He, F. Draft genome sequence of an NDM-5, CTX-M-15 and OXA-1 co-producing Escherichia coli ST167 clinical strain isolated from a urine sample. J. Glob. Antimicrob. Resist. 2018, 14, 284-286. [CrossRef] [PubMed]

51. Khatoon, Z.; McTiernam, C.H.D.; Suuronen, E.J.; Mah, T.F.; Alarcon, E.I. Bacterial biofilm formation on implantable devices and approaches to its treatment and prevention. Heliyon 2018, 4, 1-36. [CrossRef]

Publisher's Note: MDPI stays neutral with regard to jurisdictional claims in published maps and institutional affiliations.

(C) 2020 by the authors. Licensee MDPI, Basel, Switzerland. This article is an open access article distributed under the terms and conditions of the Creative Commons Attribution (CC BY) license (http://creativecommons.org/licenses/by/4.0/). 